УДК: 330.339.1

JEL Classification: O31, M31, F63, P17

DOI 10.35433/ISSN2410-3748-2020-2(27)-4

\author{
Olena Kalinichenko, \\ PhD, Senior Lecturer \\ Department of Economics,
}

management, marketing and hotel and restaurant business

Ivan Franko Zhytomyr State University

ORCID 0000-0002-5213-1649

Kateryna Kaschuck,

PhD, Senior Lecturer

Department of Economics,

management, marketing and hotel and restaurant business

Ivan Franko Zhytomyr State University

ORCID 0000-0002-4916-6867

\title{
INNOVATIVE MARKETING COMPLEX: ITS COMPONENTS, METHODS AND TOOLS
}

The article examines the state of innovation system in Ukraine. This state is defined as a crisis and such that it does not correspond to the current level in countries that have taken the path of innovative development. Low indicators were revealed that characterize innovative activity in industry, the state of which directly affects the rates of development in almost all sectors of the economy. It has been established that in order to develop an enterprise, increase its competitiveness and achieve leadership positions, it is necessary to observe two areas of activity - to develop and implement innovations and implement marketing complex activities aimed at the commercialization of innovations. The main factors that significantly affect the decision of enterprises to develop and implement innovative projects, as well as those factors that hinder the implementation of innovative activities have been determined. An approach to the formation of an innovative marketing complex is proposed. The approaches and positions to the marketing of innovations at the enterprise are determined, their influence on the efficiency of the

enterprise is indicated. Marketing in the management of enterprise development is

characterized. A systematic analysis of approaches to determining the role and place of marketing in the innovation sphere has been carried out. The practice of using marketing tools and methods in the domestic enterprises innovation activities is analyzed. The characteristics that determine the specifics of modern innovation marketing tools are determined. A complex of innovative marketing is proposed. The ways of financing innovative activity of Ukrainian

(C) Kalinichenko Olena, Kaschuck Kateryna 
enterprises are investigated. The authors refer to the search for partners for innovation activities

(suppliers, intermediaries, consumers, financial institutions, etc.) as an important aspect of increasing the effectiveness of innovative marketing. The ways of further development of marketing innovations' tools and methods and their practical application are outlined.

Key words: marketing of innovations, innovative activity, innovative project, innovative development, innovative business, commercialization.

\section{ІННОВАЦЙНИЙ КОМПЛЕКС МАРКЕТИНГУ: ЙОГО КОМПОНЕНТИ, МЕТОДИ ТА ІНСТРУМЕНТИ}

В статті розглянуто стан інновачійної діяльності в Украйні. Визначено ичей стан кризовим та таким, щзо не відповідає сучасному рівню в країнах, які стали на шлях інноваційного розвитку. Виявлено низькі показники, щзо характеризують інноваційну діяльність у промисловості, стан якої безпосередньо впливає на темпи розвитку практично усіх галузей економіки. Встановлено щзо для розвитку підприємства, підвищення своєї конкурентоспроможності і зайняті лідерських позицій, необхідно дотримуватись двох напрямків діяльності - розробляти та впроваджувати інноващії $i$ реалізовувати заходи комплексу маркетингу, щзо спрямовані на комерціалізацію інновачій. Визначено основні фактори, які суттєво впливають на рімення підприємств розробляти і реалізовувати інноваційні проекти, а також ті, які стримують здійснення інноваційної діяльності. Запропоновано підхід до формування комплексу інноваційного маркетингу. Визначено підходи та позииї̈ до маркетингу інноващій на підприємстві, вказано їх вплив на ефективність діяльності підприємства. Охарактеризовано маркетинг в управлінні розвитком підприємства. Виконано системний аналіз підходів до визначення ролі і місия маркетингу в інновачійній сфері. Виконано аналіз практики застосування інструментів і методів маркетингу в інноваційної діяльності вітчизняних підприємств. Окреслено характеристики, щзо визначають специфіку сучасного інструментарію маркетингу інновацій. Запропонований комплекс інноваційного маркетингу. Досліджено шляхи фінансування інноваційної діяльності підприємств Украӥни. До важливого аспекту підвищення ефективності інноваційного маркетингу віднесено пошук партнерів (постачальників, посередників, споживачів, кредитнофінансових установ тощо) для інноващійної діяльності. Намічено шляхи подальшого розвитку інструментів та методів маркетингу інновацій та їх практичного застосування.

Ключові слова: маркетинг інновачій, інноваційна діяльність, інноваційний проект, інноваційний розвиток, інноваційний бізнес, комериііалізація.

\section{Problem statement in general and its connection with important} scientific and practical problems. The modern economy of Ukraine is characterized by a high level of dynamism and instability. The same situation is typical for other countries that have embarked on the path of market transformation, and given the crisis in the world economy, it can be noted that this applies to almost all countries. Of course, this negatively affects the activities of business entities, since they are not always able to quickly adapt to changes in the external environment. In order to bring the internal development opportunities of 
enterprises in line with market conditions, one of the smartest means at the moment is to create and disseminate innovations.

Practice shows that almost all enterprises that successfully develop in the market owe their success to innovations. Indeed, the regular introduction into production and promotion of new products on the market provide a greater degree of consumer satisfaction than traditional ones, capable of providing and maintaining a constant, unquenchable interest in the innovator. But the facts prove that the development and commercialization of new developments is a very difficult and risky business. About 100 thousand items of new products are annually introduced to the world market, of which only $2 \%$ are real innovations.

Thus, marketing plays one of the leading roles in ensuring the success of the market activity of an enterprise-innovator. This role consists in the orientation of production and sales to a fuller than competitors' satisfaction of existing consumer needs with the help of various kinds of innovations, in the formation and stimulation of demand for fundamentally new innovative goods (both products and services) designed to meet the needs in a new way, as well as latent (implicit) needs or new needs $[14,16,19]$.

Based on the foregoing, in order for an enterprise to develop, increase its competitiveness and take a leading position, it is necessary to observe two areas of activity - to develop and implement innovations and implement marketing complex activities aimed at commercializing innovations. The famous scientist in the field of marketing and management F. Kotler spoke about this in the middle of the last century [12].

Analysis of recent research and publications. The problem of marketing support for innovative activities has been studied by many foreign and domestic scientists. Aspects of innovation marketing are described in the works of F. Kotler [12], D. Crevens [13]. Among the specialists who in their works single out marketing as one of the most important factors for the success of innovative activities, it should be noted such as: L.V. Balabanova [1], I. Berezin [2], N.V. Belotserkovskaya [3], J. Goldstein [4], N.N. Ermoshenko [6], N.S. Ilyashenko [7], 
S.M. Ilyashenko [8], B. Kiselev [9], N.Yu. Konina [10], O.P. Kostina [11], Ya. Matveev [14], Ya.S. Matkovskaya [15], L.N. Ogoleva [16], F. Pavlenko [17], M. Porter [18] and others. Scientists have deeply worked out the methodological and theoretical-methodological foundations of innovation marketing and innovative marketing. However, the applied aspects of the application of methods and tools for marketing innovations, as well as innovative marketing tools in the activities of domestic producers have remained insufficiently studied.

The purpose of the work is to analyze the role and place of marketing innovations in the activities of domestic enterprises and institutions, to outline the range of marketing tools and methods that they use.

Presentation of the main research material. The state of innovation activity in Ukraine is defined by the majority of scientific experts as a crisis and such that does not correspond to its current level in countries that have embarked on the path of innovative development. Of particular concern are the low indicators characterizing innovative activity in industry, the state of which directly affects the rate of development of almost all sectors of the economy.

According to available data during 2000-2019. the share of industrial enterprises in Ukraine that were engaged in innovative activities ranges from 14.8 to $13.8 \%$. In 2019 , the share of innovative enterprises amounted to $15.8 \%$ of the total number of those surveyed [5].

In any case, the number of enterprises that are not engaged in innovative activities significantly exceeds the number of innovative enterprises, and this indicates a deepening gap with countries that are leaders in innovative growth.

The main factors that significantly affect the decision of enterprises to develop and implement innovative projects or hinder the implementation of innovative activities include:

- low demand for innovations in the market;

- preliminary innovations (possibly unsuccessful)

- low competitiveness of the enterprise in the market;

- lack of new ideas or implementation opportunities; 
- lack of funds at the enterprise;

- no loans or direct investments;

- inconsistency of the qualifications of the company's employees with the new market requirements;

- lack of established cooperation with other enterprises and countries;

- low demand for innovative ideas;

- high competition in the market [11, p. 50-52].

In our opinion, the most significant factor that prevents enterprises from carrying out innovative activities is the fact that they do not feel the need for it. However, as noted, it is innovation and innovation that is an effective means of ensuring conditions for long-term survival and development of enterprises in the market, which allows them to adapt to permanent changes in the conditions of the external macro- and microenvironment, and, ideally, to program these changes. In this situation, innovation marketing allows you to identify market opportunities and threats and, in comparison with the strengths and weaknesses of the enterprise, determine the areas of innovation that will allow you to realize favorable opportunities and avoid or counteract unfavorable ones. And new marketing tools and methods (marketing innovations) will allow us to promote innovations in the market and satisfy consumer needs in a better way than competitors. Marketing of innovations should be considered as innovative marketing, involving the identification of new needs and demands of consumers (or their formation - for radical innovations) and the use of innovative marketing tools to satisfy them [7, p. $58]$.

Marketing innovation is a concept according to which an organization must continuously improve products and marketing methods, carry out research and development, organize the innovations production, market research (using benchmarking elements), establish communications, form prices and develop innovative strategies. Marketing innovations can also be viewed from such positions [1, p. 270]: 
1) as an analytical process that involves identifying market opportunities for innovative development;

2) as a mean of active influencing consumers and the target market as a whole, which is associated with the introduction and promotion of innovation to the market

3) as a function of innovation management, aimed at identifying possible areas of innovation, their materialization and commercialization. At the same time, it is possible to simultaneously consider innovation management as a function of marketing innovations aimed at translating the achievements of science and technology into new products that can satisfy the needs and demands of consumers and provide a profit for the producer (seller);

4) as a mean (market tool) of individual economic entities orientation, and at the same time of the national economy as a whole, towards innovative development.

Based on the analysis of modern approaches to the components of the marketing complex [8, p. 27] we propose an approach to the formation of innovative marketing complex. The innovative marketing complex is schematically shown in Fig. 1.

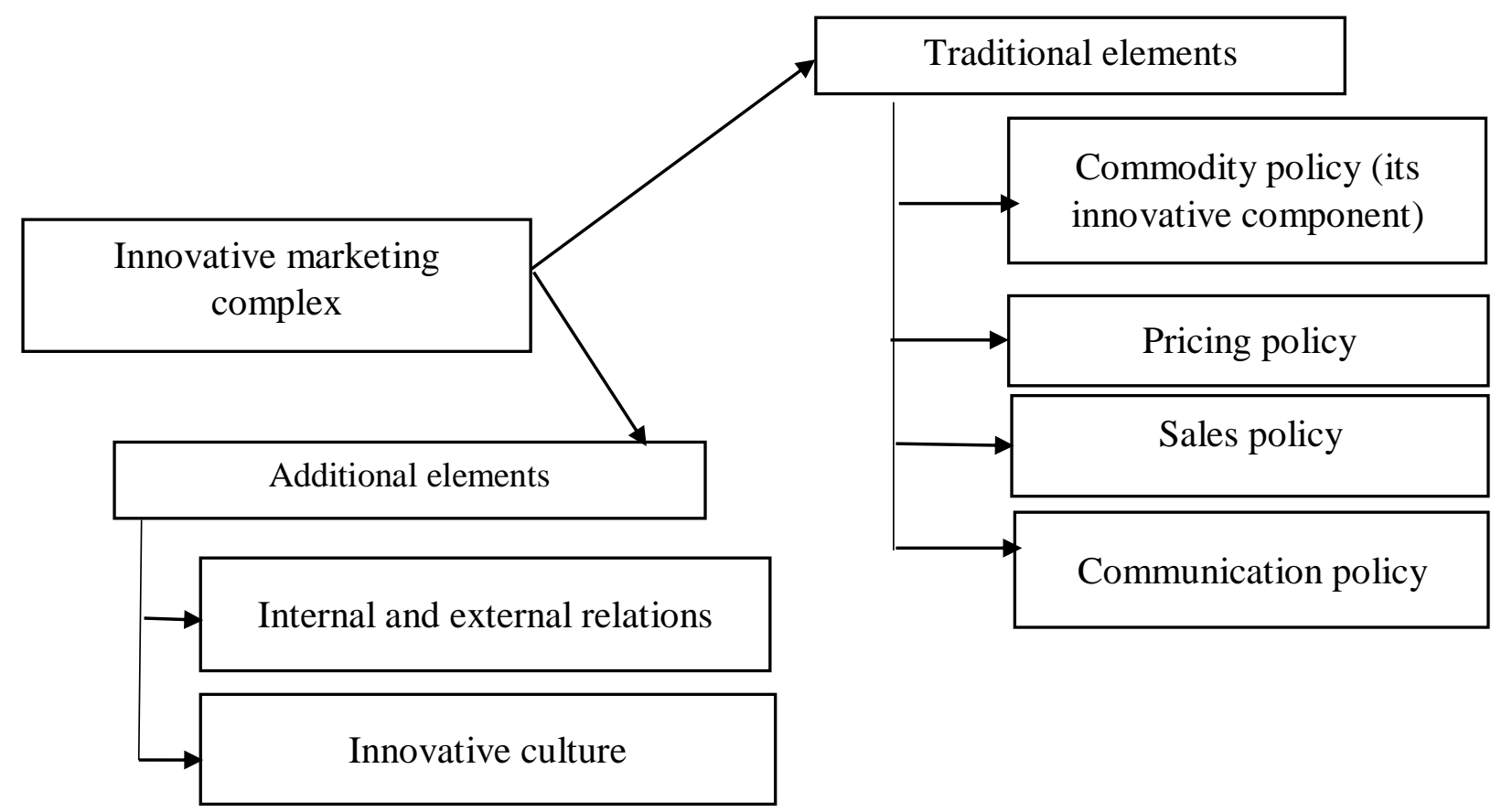

Fig. 1. Innovative marketing complex components 
Based on Fig. 1, the components of the complex are, first of all, four traditional elements, that is, the commodity, price, sales and communication policies of the enterprise. They are the basis of marketing in general and it is they that allow the company to function in market conditions. It is proposed to use the following as additional elements:

1. External and internal relations of the enterprise (in English "people") - this is the relationship with the main counterparties and communications at the enterprise itself. The allocation of this component is associated with the development of the information economy, which is understood as the production system in combination with the sphere of consumption, where information is the leading productive force (the decisive means and the object of labor), as well as the main product of production and the object of consumption [11, p. 45-46].

The communication of the enterprise is the basis for receiving information and the possibility of making appropriate decisions. Thus, the relationship at different levels of the enterprise is an integral part of its successful functioning. Analysis of existing relationships and the development of new ones allow the company to better implement its economic activities in order to achieve its goals. Thus, the main tasks within this component of the innovative marketing complex are:

- collection of information about the main subjects with which the company cooperates and contacts and its analysis;

- establishing long-term and contacts with contractors, increasing the efficiency of cooperation with them;

- improving the level of communication with personnel.

2. The innovative culture of an enterprise (in English "culture") is a corporate culture, which is basically aimed at innovations, their constant generation and implementation. This component is responsible for the process of the enterprise's transition to innovative development by increasing the understanding of all its employees about the need for this process. That is, only the 
work of all elements of the enterprise system, their cooperation and interconnection of actions will allow the enterprise to develop effectively on the basis of innovative marketing. The development of an innovative culture should be one of the main tasks of the top management of the enterprise.

Considering the above, the proposed by us innovative marketing complex can be written in the form of the following formula: " $5 \mathrm{P}+\mathrm{C}$." Based on the tools of the innovative marketing complex, the enterprise develops and implements innovative projects $[8$, p. 32].

In an innovative business, the issues of organizing marketing activities are of fundamental importance. However, in small companies, these very issues are often left out of the focus of the leader, who focuses on the development of a new product. As a result, many projects fail. Therefore, starting the preparation of a new project, it is necessary to pay special attention to the organization of a special unit that will deal with the marketing of new developments and their implementation.

3. Innovation teams are groups that are engaged in innovation, including in marketing, and should consist of specialists from different fields who are united by the ability and desire to work on new approaches, products or services, the absence of fear of failure, freedom of ideas and thoughts. It must include people from the top management level and those who are directly responsible for the company's development strategy. They are the ones who must realize the need for innovative marketing in order for ideas to come true and give the desired result. After all, innovative marketing can also affect the issues of reducing the organization's resources for the implementation of a particular activity, for example, innovation in the process of producing a new product and delivering it to the consumer. Perhaps the innovative model will consist in the partial transfer of the production process to other contractors or even to the consumer himself, as IKEA did when it began to sell disassembled furniture [6, p. 158]. And this is also innovative marketing, since such a solution has significantly reduced collection costs and reduced the cost of goods, from which both the company and the buyer benefitted. 
As for the financing of innovative activities at innovative enterprises in Ukraine, in 2019 it was mainly carried out at the expense of own funds (about 97.2\% of the total volume of financing, in 2014 - about 90\%), the share of other sources was extremely insignificant: foreign investors $-0.4 \%$; budget funds - less than $0.4 \%$; other sources - about $2 \%$ [5].

An important aspect of innovative marketing is finding partners for innovation (suppliers, intermediaries, consumers, financial institutions, etc.). Their interest in the innovations that a business can create significantly increases its chances of commercial success. From this point of view, an important marketing task is to identify (form) the interests of possible economic counterparties (subjects of the innovation process) and take them into account both in the characteristics of manufactured products and in the methods of their promotion and marketing.

Conclusion. The generalization of the foregoing indicates that the innovative activity of enterprises requires appropriate marketing support. With the help of marketing tools, promising directions for bringing the potential of the enterprise into line with the conditions of the external environment, which are constantly changing, are determined. That is, the directions for the creation and implementation of innovations (new products, technologies for their manufacture, management methods, etc.), which allow the enterprise to adapt to changes in the conditions of the external macro- and microenvironment.

Application of marketing methods and tools at innovative enterprises has shown that marketing plays an important role in ensuring the effectiveness of their innovative activities. However, the scale of its application is insufficient. So, only $44.8 \%$ of innovatively active enterprises introduced marketing innovations, although some tools and methods of marketing innovations were used by almost all enterprises. Considering that the share of innovatively active enterprises is very insignificant, it can be concluded that their leaders are not paying enough attention to marketing innovations.

This does not allow to timely respond to changes in market conditions, identify and analyze market opportunities and threats, and find ways of survival 
and development in new conditions. That is, to determine the directions of innovation activities that will allow to determine and strengthen the comparative competitive advantages of domestic enterprises in the national and international markets, to provide conditions for their innovative growth. Accordingly, it is necessary to increase attention to the use of marketing tools by domestic producers.

Further research should be aimed at scientific substantiation of rational ways of using innovation marketing tools to increase the efficiency of innovation activities of domestic producers.

\section{REFERENCES}

1. Balabanova, L.V. (2002). Marketynh [Marketing]. Donetsk: HNOMPRESS [in Ukrainian].

2. Berezin, I. (2011). Rynok marketingovykh issledovanii i konsaltinga: sostoianiie, problemy, perspektivy [Marketing research and consulting: state, problems and prospects]. Prakticheskii marketynh - Practical marketing, 3, 156168 [in Russian].

3. Bilotserkivska, N.V. (2014). Marketynhovi innovatsii: pidkhody, vydy, utrymannia $i$ vykorystannia [Marketing innovations, approaches, views, maintenance and use]. Kiev: Visnyk ODU [in Ukrainian].

4. Goldshtein, G.Ya. (2002). Stratehicheskii innovatsioni menedzhment [Strategic innovation management]. Taganrog: TRTU. Retrieved from: http://www.aup.ru/books/m78/5_5.htm [in Russian].

5. Promyslovist Ukrainy u 2018-2019 rokakh: statystychnyi zbirnyk [Industry of Ukraine in 2018-2019: Statistical Yearbook]. (2020). Kyiv: Derzhavnyi komitet statystyky Ukrainy [in Ukrainian].

6. Yermoshenko, M. M. (2001). Marketynhovyj menedzhment [Marketing Management]. Kiev: NAU [in Ukrainian].

7. Illiashenko, N.S. (2011). Orhanizatsiyno-ekonomichni zasady innovatsiinoho marketynhu promyslovykh pidpryiemstv [Organizational and economic bases of innovative marketing industry]. Sumy: SumDU [in Ukrainian]. 
8. Illiashenko, S.M. (2016). Innovatsiynyi rozvytok: marketynh $i$ menedzhment znan [Innovative development, marketing and management knowledge]. Sumy: Disa plius [in Ukrainian].

9. Kyselov, B. (2007). Stratehichieskiie faktory uspekha marketinhovykh innovatsiy [Strategic success factors of marketing innovation]. Marketynh Marketing, 3, 229-241 [in Russian]

10. Konyna, N.Y. (2009). Marketinh i konkurientnyie pozitsii TNK [Marketing and competitive position of TNK]. Marketynh-Marketing, 5, 151-169 [in Russian]

11. Kostina, O. P. (2003). Marketynh innovatsii v promishlennosti [Innovative Marketing in Industry]. Kasan:Vestnik TYSBY [in Russian].

12. Kotler, F. (2006). Marketinh menedzhment [Marketing Management]. Saint Petersburg: Piter [in Russian].

13. Krevens, D. (2003). Stratehichnyi marketynh [Strategic Marketing]. Moscow: Viliams [in Russian].

14. Matviiv, M.Y.(2014). Innovatsiinyi marketynh pidpryiemstv [Innovative Marketing companies]. Ternopil: TNEU [in Ukrainian].

15. Matkovskaia, Y. (2010). Komertsializatsiia rynkovykh innovatsii paradihma innovatsionnoho marketinha [Market commercialization of innovations - innovative marketing paradigm]. Moscow: Hrebennykov [in Russian].

16.Oholeva, L. N. (2009). Innovatsionnyi menedzhment [Innovative Management]. Moscow: Ynfra-M [in Russian].

17. Pavlenko, A.F. \& Voichak, A.V. (2003). Marketynh [Marketing]. Kiev: KNEU [in Ukrainian].

18. Porter, M. (1998). Stratehiia konkurentsii [Competitive strategy]. New York: The Free Press [in English].

19. Pashuta, M. T. (2005). Innovatsii: poniatiyno-terminolohichnyi aparat, ekonomichna sutnist ta shliakhy stymuliuvannia [Innovation: concepts and terminology, and how the economic substance stimulation]. Kiev: TsUL [in Ukrainian]. 
Стаття надійила до редакиії 29.10.2020

(C) Kalinichenko Olena, Kaschuck Kateryna 